Chapman University

Chapman University Digital Commons

\title{
Surveillance, Epidemiological, and Virological Detection of Highly Pathogenic H5N1 Avian Influenza Viruses in Duck and Poultry from Bangladesh
}

Wahedul Karim Ansari

Bangladesh Agricultural University

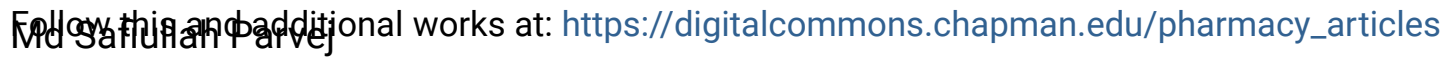

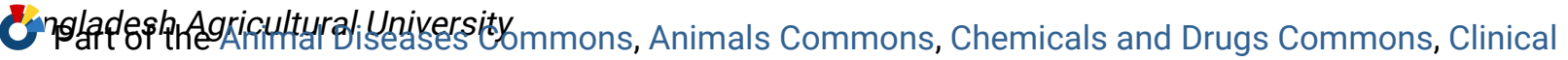

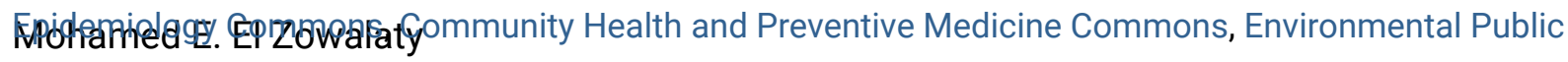

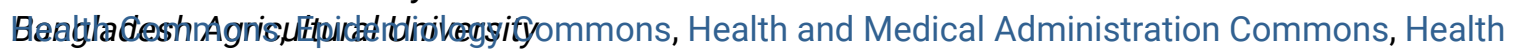
Services Research Commons, Influenza Humans Commons, Influenza Virus Vaccines Commons,
Sally Jackson

Bangratadesh Agricuitüuraltuniversity

Commons, Medical Immunology Commons, Medical Pharmacology Commons, Other Public Health

Stephen A, Bustineterinary Medicine Commons, Poultry or Avian Science Commons, Preventive Anglia Ruskin University

Medicine Commons, Public Health Education and Promotion Commons, Veterinary Infectious Diseases

Commons, Veterinary Pathology and Pathobiology Commons, Veterinary Preventive Medicine,

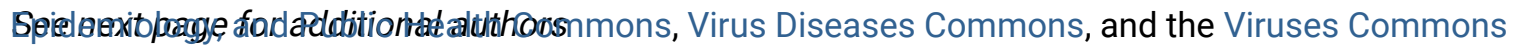

\section{Recommended Citation}

Ansari, W.K., Parvej, M.S., El Zowalaty, M.E., Jackson, S., Bustin, S.A., Ibrahim, A.K., El Zowalaty, A.E., Rahman, M.T., Zhang, H., Khan, M.F.R., Ahamed, M.M., Rahman, M.F., Rahman, M., Nazir, K.H.M.N.H., Ahmed, S., Hossen, M.L., Kafi, M.A., Yamage, M., Debnath, N.C., Ahmed, G., Ashour, H.M., Masudur Rahman, M., Noreddin, A., Rahman, M.B., 2016. Surveillance, epidemiological, and virological detection of highly pathogenic H5N1 avian influenza viruses in duck and poultry from Bangladesh. Veterinary Microbiology, 193, 49-59. doi:10.1016/j.vetmic.2016.07.025

This Article is brought to you for free and open access by the School of Pharmacy at Chapman University Digital Commons. It has been accepted for inclusion in Pharmacy Faculty Articles and Research by an authorized administrator of Chapman University Digital Commons. For more information, please contact laughtin@chapman.edu. 


\section{Surveillance, Epidemiological, and Virological Detection of Highly Pathogenic H5N1 Avian Influenza Viruses in Duck and Poultry from Bangladesh}

\section{Comments}

NOTICE: this is the author's version of a work that was accepted for publication in Veterinary

Microbiology. Changes resulting from the publishing process, such as peer review, editing, corrections, structural formatting, and other quality control mechanisms may not be reflected in this document. Changes may have been made to this work since it was submitted for publication. A definitive version was subsequently published in Veterinary Microbiology, volume 193, in 2016. https://doi.org/10.1016/ j.vetmic.2016.07.025

The Creative Commons license below applies only to this version of the article.

\section{Creative Commons License}

\section{(c) (i) $\odot$}

This work is licensed under a Creative Commons Attribution-Noncommercial-No Derivative Works 4.0 License.

\section{Copyright}

Elsevier

\section{Authors}

Wahedul Karim Ansari, Md Safiullah Parvej, Mohamed E. El Zowalaty, Sally Jackson, Stephen A. Bustin, Adel K. Ibrahim, Md Tanvir Rahman, Han Zhang, Mohammad Ferdousur Rahman Khan, Md Mostakin Ahamd, Md. Fasiur Rahman, Marzia Rahman, KHM Nazmul H. Nazir, Sultan Ahmed, Md Liakot Hossenn, Md Abdul Kafi, Mat Yamage, Nitish C. Debnath, Graba Ahmed, Hossam Ashour, Md Masoud, Ayman Noreddin, and Md B. Rahman 


\section{Accepted Manuscript}

Title: Surveillance, epidemiological, and virological detection of highly pathogenic H5N1 avian influenza viruses in duck and poultry from Bangladesh

Author: Wahedul Karim Ansari Md Safiullah Parvej

Mohamed E. El Zowalaty Sally Jackson Stephen A. Bustin

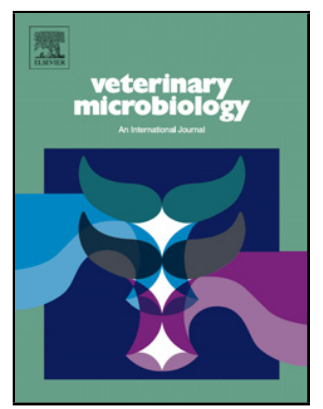
Adel K. Ibrahim Md Tanvir Rahman Han Zhang Mohammad Ferdousur Rahman Khan Md Mostakin Ahamd Md. Fasiur Rahman Marzia Rahman K.H.M. Nazmul H. Nazir Sultan Ahmed Md Liakot Hossenn Md Abdul Kafi Mat Yamage Nitish C. Debnath Graba Ahmed Hossam Ashour Md Masoud Ayman M Norredin Md B. Rahman

$\begin{array}{ll}\text { PII: } & \text { S0378-1135(16)30202-4 } \\ \begin{array}{l}\text { DOI: } \\ \text { Reference: }\end{array} & \begin{array}{l}\text { http://dx.doi.org/doi:10.1016/j.vetmic.2016.07.025 } \\ \text { VETMIC 7353 }\end{array} \\ \text { To appear in: } & \text { VETMIC } \\ & \\ \text { Received date: } & 21-7-2016 \\ \text { Accepted date: } & 31-7-2016\end{array}$

Please cite this article as: Ansari, Wahedul Karim, Parvej, Md Safiullah, El Zowalaty, Mohamed E., Jackson, Sally, Bustin, Stephen A., Ibrahim, Adel K., Rahman, Md Tanvir, Zhang, Han, Khan, Mohammad Ferdousur Rahman, Ahamd, Md Mostakin, Rahman, Md.Fasiur, Rahman, Marzia, Nazir, K.H.M.Nazmul H., Ahmed, Sultan, Hossenn, Md Liakot, Kafi, Md Abdul, Yamage, Mat, Debnath, Nitish C., Ahmed, Graba, Ashour, Hossam, Masoud, Md, Norredin, Ayman M, Rahman, Md B., Surveillance, epidemiological, and virological detection of highly pathogenic H5N1 avian influenza viruses in duck and poultry from Bangladesh. Veterinary Microbiology http://dx.doi.org/10.1016/j.vetmic.2016.07.025

This is a PDF file of an unedited manuscript that has been accepted for publication. As a service to our customers we are providing this early version of the manuscript. The manuscript will undergo copyediting, typesetting, and review of the resulting proof before it is published in its final form. Please note that during the production process errors may be discovered which could affect the content, and all legal disclaimers that apply to the journal pertain. 


\section{Surveillance, epidemiological, and virological detection of highly pathogenic H5N1 avian}

\section{influenza viruses in duck and poultry from Bangladesh}

Wahedul Karim Ansari ${ }^{1, \dagger} \cdot$ Md Safiullah Parvej ${ }^{1, \dagger} \cdot$ Mohamed E. El Zowalaty ${ }^{1, \mathbb{I l}, \varpi} \cdot$ Sally

Jackson $^{1} \cdot$ Stephen A. Bustin ${ }^{2} \cdot$ Adel K. Ibrahim ${ }^{3} \cdot$ Md Tanvir Rahman $^{1} \cdot$ Han Zhang ${ }^{4}$ •

Mohammad Ferdousur Rahman Khan ${ }^{1} \cdot$ Md Mostakin Ahamd $^{1} \cdot$ Md. Fasiur Rahman ${ }^{1}$ Marzia

Rahman $^{5} \cdot$ KHM Nazmul H. Nazir ${ }^{1} \cdot$ Sultan Ahmed $^{1} \cdot$ Md Liakot Hossenn $^{1} \cdot$ Md Abdul Kafi ${ }^{1} \cdot$

Mat Yamage ${ }^{6} \cdot$ Nitish C. Debnath $^{6} \cdot$ Graba Ahmed $^{6} \cdot$ Hossam Ashour, $^{7}$ Md Masoud, ${ }^{8}$ Ayman

M Norredin ${ }^{9} \cdot$ Md B. Rahman ${ }^{1}$

${ }^{1}$ Department of Microbiology and Hygiene, Bangladesh Agricultural University, Mymensingh, Bangladesh

${ }^{2}$ Postgraduate Medical Institute, Anglia Ruskin University, Chelmsford, UK

${ }^{3}$ Department of Clinical Pathology, Faculty of Veterinary Medicine, Cairo University, Egypt

${ }^{4}$ Department of Microbiology and Immunology, Emory University School of Medicine, Atlanta, Georgia, USA

${ }^{5}$ Mymensingh Medical College Hospital, Mymensingh, Bangladesh

${ }^{6}$ Emergency Center for Transboundary Animal Diseases (ECTAD), Food and Agriculture Organization (FAO) of the United Nations, Bangladesh

${ }^{7}$ Department of Pathology, Faculty of Veterinary and Animal Science, Sylhet Agricultural University, Sylhet, Bangladesh

${ }^{8}$ Department of Microbiology and Immunology, Wayne State University, Michigan, USA

${ }^{9}$ School of Pharmacy, Chapman University, Irvine, CA, USA

Corresponding author: $₫$ Mohamed E.El Zowalaty elzow001@gmail.com

${ }^{\dagger}$ Equal first authors. $\quad$ "Second author 


\section{Highlights}

The authors present data from a surveillance study conducted in Bangladesh on circulation of H5N1 in chickens and ducks. This manuscript describes significant information and has merit about prevalence and circulation of avian influenza viruses in poultry through intensive surveillance in Bangladesh. Great efforts have been taken for virus detection and subtyping. The interesting finding appears to be the absence of high levels of antibody in vaccinated chickens, beside the detection and circulation of H5N1 strains.

This is a revision of the first round review and a major revision was the decision. 


\begin{abstract}
Avian influenza viruses (AIVs) continue to pose a global threat. Waterfowl are the main reservoir and are responsible for the spillover of AIVs to other hosts. This study was conducted as part of routine surveillance activities in Bangladesh and it reports on the serological and molecular detection of H5N1 AIV subtype. A total of 2169 cloacal and 2191 oropharyngeal swabs as well as 1725 sera samples were collected from live birds including duck and chicken in different locations in Bangladesh between the years of 2013 and 2014. Samples were tested using virus isolation, serological tests and molecular methods of RT-PCR. Influenza A viruses were detected using reverse transcription PCR targeting the virus matrix (M) gene in 41/4360 (0.94\%) samples including both cloacal and oropharyngeal swab samples, 31 of which were subtyped as H5N1 using subtype-specific primers. Twenty-one live H5N1 virus isolates were recovered from those 31 samples. Screening of 1,868 blood samples collected from the same birds using H5-specific ELISA identified 545/1603 (34\%) positive samples. Disconcertingly, an analysis of 221 serum samples collected from vaccinated layer chicken in four districts revealed that only 18 samples $(8.1 \%)$ were seropositive for anti $\mathrm{H} 5$ antibodies, compared to unvaccinated birds $(\mathrm{n}=105)$, where 8 samples $(7.6 \%)$ were seropositive. Our result indicates that the vaccination program as currently implemented should be reviewed and updated. In addition, surveillance programs are crucial for monitoring the efficacy of the current poultry vaccinations programs, and to monitor the circulating AIV strains and emergence of AIV subtypes in Bangladesh.
\end{abstract}

Keywords: Avian Influenza, H5N1, surveillance, Bangladesh, duck, wild birds, poultry, live bird markets 


\section{Abbreviations:}

AIVs = avian influenza viruses;

$\mathrm{C}=$ Cloacal

$\mathrm{NDV}=\mathrm{Newcastle}$ diseases virus

$\mathrm{ECE}=$ embryonating chicken egg;

HA = hemagglutinin; hemagglutination

HPAI = highly pathogenic avian influenza;

IAVs= Influenza A viruses

LBM=live bird markets

LPAI = low pathogenic avian influenza;

NA = neuraminidase;

$\mathrm{OP}=$ oropharyngeal

OIE = Office International des Epizooties (World Organization for Animal Health);

RT-PCR = reverse transcription-polymerase chain reaction;

qRRT-PCR= quantitative real time reverse transcription-polymerase chain reaction

$\mathrm{SPF}=$ specific pathogen free.

$\mathrm{VI}=$ virus isolation 


\section{Introduction}

Avian influenza (AI) is responsible for several epizootics and poses a continuous worldwide threat to agricultural biosecurity and public health since the 1996-1997 emergence of H5N1 avian influenza virus (HPAIV) in Hong Kong [1]. Originally circulating in poultry in Asia, the virus has spread to more than 60 countries in Africa, Europe, Middle East, and the United States [2]. Infections with avian influenza viruses (AIVs) are notifiable "Listed-diseases" per the Office International des Epizooties (OIE) [3], and the viruses are categorized into two pathotypes based on their virulence in chickens : the "highly pathogenic" avian influenza (HPAI) and the "low pathogenic" avian influenza (LPAI) [4]. AIVs are further classified into different subtypes on the basis of antigenic differences in hemagglutinin (HA) and neuraminidase (NA), two viral surface glycoproteins. HPAI causes routine waves of high mortality in susceptible poultry and human cases have also been reported in individuals with direct contact with infected poultry. As of February 2016, the mortality rate of HPAI viruses in humans was reported to be $53.07 \%$ (449 deaths out of 846 reported cases) [5].

Bangladesh is one of the most densely populated countries in the world, both for human (1072 people/ $\mathrm{km}^{2}$ ) and poultry populations (1194 birds/ $\mathrm{km}^{2}$ ) [6-8], with seven confirmed HPAIV cases including one fatality reported to date (July, 2015) [9]. According to the OIE and the United Nations Food and Agriculture Organization (FAO), Bangladesh and its neighboring countries (Myanmar, Bhutan, Nepal, China, and Indonesia) are endemic for HPAIV [10]. This is a major public health concern and since the poultry industry in an agriculture-based economy like Bangladesh comprises $20 \%$ of the livestock sector, the continuous culling of an estimated more than 250 million infected animals [11] is causing an increase in food insecurity [12] as well as affecting economic growth [13]. Low and highly pathogenic avian influenza A virus subtypes 
including highly pathogenic H5N1 avian influenza virus subtype among waterfowl, pet birds, and poultry were reported from Bangladesh [14-18]

The epidemiology of avian influenza is a complex phenomenon. Live bird markets (LBM) are considered to be man-made reservoirs of AIVs, as backyard chickens and ducks play a significant role in the epidemiology and transmission of these viruses $[19,20]$. The recent human infections with avian-origin H7N9 and H10N8 AIVs in China highlight the importance and role of domestic ducks as intermediary mixing vessels for various AIVs subtypes and transmitting them to chickens and humans [21]. Cross-species infection of AIV occurs sporadically between birds (class Aves) and mammals (class Mammalia), including swine, horses, mink, marine mammals, and humans [22]. Aquatic birds of the orders Anseriformes (dabbling ducks, geese) and Charadriformes and Procellariiformes (shorebirds, gulls, seabirds) are natural reservoirs of AIVs [23] as AIVs replicate predominantly in the epithelial lining of their intestinal tract and are shed with feces into the water [24]. Since they are migratory, this is likely to provide an important route in the spread of AIVs through fecal-oral transmission.

The potential transmission of AI to humans reinforces the need for continuous monitoring programs for the containment of AIVs in waterfowl and poultry [25] and is essential for the early detection of emerging viruses, understanding their ecology, tracking the circulating strains, monitoring the dynamics of infection and, ultimately, controlling the disease [26]. To date, 16 HA and 9 NA subtypes have been detected in and isolated from wild birds (ducks, geese, and shorebirds) [27], while two additional subtypes, $\mathrm{H} 17$ and H18, have been isolated from bat populations in South America [28, 29].

Diagnosis of AI in animal populations is based on the use of both molecular and virus isolation (VI) techniques [30] which can detect both infectious and noninfectious viral particles, 
respectively, are widely utilized for AIV surveillance programs [31]. Conventional RT-PCR is not ideal if large numbers of samples need to be analyzed, since cross contamination can easily occur and must be minimized through good laboratory practice, compartmentalization of the PCR process and unidirectional flow of samples during analysis. In contrast, qRRT-PCR analysis does not require gel electrophoresis for amplicon detection, which makes the screening of influenza circulating in waterfowl at large scale easy and feasible [32]. However, whilst RTPCR-based detection methods of AIV may be appropriate for the detection of current strains circulating in a particular species [33], the genetic heterogeneity of AIVs leads to a considerable number of mismatches with the PCR primers and potential for false negative results [33]. Hence, virus isolation (VI) in embryonating specific pathogen free (SPF) chicken eggs remains the gold standard method for the detection and isolation of AIV and Newcastle disease virus (NDV) [34, 35] and is used for virus characterization to provide up-to-date antigenic information for the production of preventative vaccines [30, 31, 36-39]. However, VI is more laborious, costly, and requires highly skilled personnel [40]. Hence it is important to balance the sensitivity, specificity, feasibility, rapidity, and costs of these techniques when choosing the method most appropriate for a given situation. Indeed, making use of both approaches in parallel is recommended as such an approach results in the most comprehensive representation of circulating AIVs subtypes [41]. The dynamics and transmission of AIVs in asymptomatic infected wild migratory birds is complex and is not yet fully understood. There are few data on the surveillance of avian influenza viruses in poultry in Bangladesh Consequently, in the present study, we reported the updated prevalence of $\mathrm{H} 5 \mathrm{~N} 1$ in poultry and results of routine surveillance of avian influenza in Bangladesh conducted by serological and molecular methods using RT-PCR, virus isolation, and 
serological analysis for the ongoing surveillance of H5N1 AIVs in different locations in Bangladesh.

\section{Materials and Methods}

\section{Ethical Statement:}

All experimental and animal procedures were undertaken to ensure animal health and well-being throughout the study via enlisting three licensed veterinarians from the sampling districts to collect sera and swabs from the birds. Additionally, the study was approved by and in accordance with the requirements the Institutional Animal Care and Use Committee (IACUC) at the Bangladesh Agricultural University. Permissions to conduct the study and collect samples were obtained from the Bangladesh Department of Livestock Services (DLS), Krishi Khamar Sarak, Farmgate, Dhaka-1215, and from farm owners and household to conduct study onsite

\section{Location}

Samples were collected form four geographically diverse sites in Bangladesh through a 17month period from June 2013 to October 2014: Sample sites were limited to four different

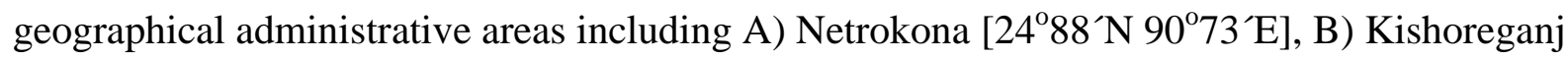

$\left[24^{\circ} 4333^{\prime} \mathrm{N} 90^{\circ} 7833^{\prime} \mathrm{E}\right]$, C) Sherpur $\left[25.00^{\circ} \mathrm{N} 90.00^{\circ} \mathrm{E}\right]$, and D) Rajshahi $\left[24^{\circ} 22^{\prime} \mathrm{N} 88^{\circ} 36^{\prime} \mathrm{E}\right]$, as illustrated in Fig. 1. Sites A and C are located near the Himalayan border in the northern part of Bangladesh, site B in the Dhaka division in the central region, while site D is located in the western part of Bangladesh. Each of the four sites is situated in different administrative areas of Bangladesh, with sites A, B, and C located in administrative areas bordering India. Capture locations were randomly selected farms, wet markets, and backyards from birds including commercial broiler, layer, native chicken, and ducks. 


\section{Field sampling procedures}

Cloacal $(C)(n=2169)$ and oropharyngeal $(O P)(n=2191)$ swabs as well as blood samples $(n=$ 1725) were collected. Live birds were sampled at sites in four different areas of Bangladesh (Kishorgonj, Netrokona, Rajshahi, and Sherpur) in 2013 and 2014 as was detailed in other studies $[42,43]$. Samples were kept in uninterrupted cold chain and shipped to the laboratory within $24 \mathrm{~h}$ of collection, where they were kept at $-80^{\circ} \mathrm{C}$ until further processing. As the samples were collected during routine surveillance activities, the surveillance activities varied in their sampling coverage for different areas: around $70 \%$ of samples were collected from sites in Netrokona district: 1493/2169 C, 1507/2191 OP, and 1172/1725 sera, with most Netrokona district samples collected during the second routine surveillance. Additional information about the samples collected by the different surveillance effort in each of the locations is shown in Table 1. Resources for surveillance activities, including testing kits, were limited and C and OP samples were pooled for each individual bird before testing for AI to reduce costs (Table 2).

\section{Virus isolation in embryonating chicken eggs}

For each bird, two samples (C and OP) were pooled in the laboratory and tested using a VI technique. VI was conducted using inoculation in 11-day-old specific pathogen free (SPF) embryonating chicken eggs (ECEs). Allantoic fluid was then tested for the presence of heamagglutinating viruses and HA positive samples were tested for AIV using conventional H5 and H7-specific RT-PCR [44]. AIV antigen positive field samples were tested for the presence of live virus. Virus isolation (VI) was conducted as was described previously [34]. Allantoic fluid was collected from the inoculated eggs $96 \mathrm{~h}$ post-inoculation and tested for the presence of virus by hemagglutination. Chicken RBCs suspension (1\%) were prepared in sterile phosphate 
buffered saline and stored at $4{ }^{\circ} \mathrm{C}$ for use in slide and microtiter plate HA tests as was described previously [45].

\section{Rapid AIV antigen test}

Cloacal and oropharyngeal samples were initially screened using AIV antigen detection test kits (Bionote, Korea) according to the manufacturers' instructions.

\section{Viral RNA extraction, molecular detection and subtyping of AIV isolates}

AIV positive allantoic fluid samples were subjected to total RNA extraction using the SV Total RNA Isolation System (Promega, WI, USA) according to the manufacturers' instructions as described previously [34]. RNA was eluted from the membrane using $100 \mu 1$ nuclease-free water by centrifugation at $12,000 \times g$ and the eluted RNA was quantified using Nanodrop to determine its quality. The purified RNA was free of protein, nucleases, and other contaminants and inhibitors. Purity was determined by calculating the ratio of corrected absorbance at $260 \mathrm{~nm}$ to corrected absorbance at $280 \mathrm{~nm}$; i.e., $\left(\mathrm{A}_{260}-\mathrm{A}_{320}\right) /\left(\mathrm{A}_{280}-\mathrm{A}_{320}\right)$. Pure RNA had an $\mathrm{A}_{260} / \mathrm{A}_{280}$ ratio of 1.7-1.9. RNA was kept at $-80^{\circ} \mathrm{C}$ until used as template during RT-PCR reaction. To screen for the presence of AIVs, pooled C and OP samples as well as individual C and OP samples were tested using conventional RT-PCR assay targeting the viral M gene as described previously [34, 44]. Briefly, RNA was extracted from these samples (using commercial RNA extraction kit (Qiagen, USA) and RNA was subjected to RT-PCR (Promega, USA). Viral RNA extracted from an avian influenza vaccine strain (Fnf Pharmaceuticals, Bangladesh) was used as a positive control.

M gene positive samples were subtyped using H5, H7, N1, and N9 gene-specific one-step RTPCR tests as described previously $[44,46]$. HA and $\mathrm{N}$ genes PCR products were purified using SV Minicolumn (Promega, Madison, USA) and purified gene fragments were submitted for 
sequencing using an Applied BioSystem 9700 sequencing facility located in the International Centre for Diarrheal Disease Research, Bangladesh. DNA sequencing was performed in both directions using the same mixture of primers as was used in the amplification as previously described. The sequence data were aligned with the existing influenza database using the National library of Medicine BLAST search tool available online at (www.ncbi.nlm.nih.gov) to determine the corresponding AIV subtype [34].

\section{Serological analysis}

Chicken sera were analyzed for the presence of AIV antibodies using ELISA kit (BioChek, UK) and duck sera were screened using commercial available competitive ELISA (H5 AIV Ab ELISA AniGen ELISA ${ }^{\circledR}$, BioNote, Suwon, Korea). The ELISA procedure was performed according to manufacturers' instructions as described previously [47].

\section{Statistical analysis}

The Prism V6.01 statistical software (GraphPad, San Diego, CA, USA) and the $\chi^{2}$-test or Fisher's exact test were used for statistical analysis.

\section{Results and Discussion}

Pooled, individual C, and OP samples were confirmed to be influenza A using M gene-directed RT-PCR assays and positive samples were subtyped as H5N1 using subtype-specific RT-PCR. As shown in Table 2, pooled $(C+O P)$ samples $(n=2,133)$, a single cloacal sample, and OP $(n=$ 18) samples were tested. Some samples ( $n=35 \mathrm{C}$ and $n=40$ OP) did not have enough sample in some tubes to test the sample and samples were classified as low quality and were discarded. Low quality sera samples were rejected because the samples were not clear sera and contained red blood cells. RT-PCR assays are described as less sensitive than VI techniques, the gold standard method for the detection of AIVs [35]. In the present surveillance activity, $1.9 \%$ 
(41/2152) of the total pooled, C, and OP samples were tested positive by M gene-directed RTPCR (Table 3). Of the 41 AIV-RT-PCR positive samples, only 31 samples had adequate sample volume. These 31 samples were subjected to virus isolation in ECEs and subtyping using RTPCR H5 and N1 primers. All of these 31 samples were found to be H5N1 RT-PCR positive (Table 3). However, only 21 live H5N1 isolates were recovered by VI in ECEs as confirmed by hemagglutination. This could be due to (i) poor sample quality (ii) presence of low virus titers in the original samples, (iii) the limited susceptibility of target cells (MDCK and chicken embryo cells), as previous studies have shown that not all cells are permissive to IAVs and many IAVs in avian samples could not be isolated in mammalian cell cultures or ECEs [36, 45, 46, 58, 59], and (iv) AIV subtypes other than H5N1 could exist in the samples, as has been reported in other studies $[18,45,46]$. Details of the M gene and H5N1 RT-PCR test results are shown for each district in Table 3. Results of serological testing of avian sera collected in Netrokona district using AIV H5 antibody ELISA revealed that 447/1050 (42.6\%) serum samples were found to be positive to H5 specific antibodies (Table 4, Table 5). In contrast, samples from Rajshahi and Sherpur districts were found to have a low proportion of H5 AIV positive samples $(14.4 \%$ and $22.3 \%$, respectively).

Netrokona district is one of the most duck populated area and our results are consistent with the hypothesis that ducks may play a major role as potential reservoir of H5N1AIVs where our findings showed that $42.6 \%$ ( $n=447$ out of 1050 duck samples) were found to be positive for H5 antibodies as shown in tale 5, hence duck are responsible for spreading the virus among other species. The existence of lakes and wetlands in the Netrokona area, where migratory waterfowl are grazing near to domestic birds, would facilitate the maintenance and transmission of AIVs from waterfowl into poultry and domestic duck populations. It cannot be excluded, however, 
that the differences could be a result of a relatively low sample size in these areas in combination with clustered sampling. The extent of the clustering has not been fully established in this study, as we described data reported from samples taken during routine surveillance activities and their approximate locations, and GIS mapping was not within the scope of the activities.

Chicken sera were also screened for anti-influenza antibodies other than anti H5 Abs since H5N1 is usually lethal to poultry, while anti-H5 Abs ELISA test was used to detect antibodies in duck sera since duck act as carrier or reservoir of H5N1 AIVs. The ELISA test results revealed that a large proportion of ducks was seropositive for AIV antibodies, which confirms that these ducks may provide an important reservoir for the circulating AIVs. These ELISA test results were in agreement with previous findings [48, 49]. Interestingly, the proportion of AIV positive by RTPCR in $\mathrm{C}$ and OP samples in different districts did not reflect the results from the sera samples. For instance, the district with the highest proportion of sera positive samples, Netrokona (42.6 \%) (Table 5), exhibited the lowest (1.7\%) proportion of AIV RT-PCR positive results with the C and OP samples (Table 3). This is to be expected as birds with antibodies would be shedding less-either because they have seroconverted and are not shedding as much anymore or because they have been infected in the past, exposed to AIV which acted as a boost vaccine and therefore, are not as easily re-infected again.

The finding that samples from Rajshahi (5.6\%) district showed the highest proportion of H5N1 RT-PCR positive results may be explained in part by the fact that there is long and porous border with India. These borders are not regularly monitored, where many birds could be introduced into Bangladesh illegally through black markets (disambiguation), posing a major threat in the introduction of AIVs including the HPAIV. It may be explained that this population is more secluded with a higher turn over rate. That is at any time in this area the birds have not been 
exposed to AIV to have a Ab titer and therefore when they are infected, they tend to shed more virus. The occurrence of avian influenza in other districts may be explained by additional factors including contact with the affected birds, transportation of contaminated poultry and poultry products from other regions, and the compromised biosecurity measures during handling of birds and poultry in the country. Inappropriate poultry handling practices complicate the control of avian influenza, particularly of the H5N1 AIV subtype.

As shown in Fig. 2 and fig 3, for duck samples, $(\mathrm{n}=180), 12,15,100$ and 3 samples were found positive using rapid AIV Ag test, HA, ELISA, and H5N1-based RT-PCR, respectively. The results revealed that samples collected from Netrokona district showed the highest number of positive samples. Among the chicken samples $(n=180)$, broiler chickens $(n=60)$ returned the fewest positive results, with 5, 9, 3 and 1 samples positive using rapid AIV Ag test, HA, ELISA, and H5N1-based RT-PCR, respectively. In contrast, 14, 19, 8 and 10-layer chicken samples ( $\mathrm{n}=$ 60) were positive using AIV Ag test, HA, ELISA, and H5N1-based RT-PCR, respectively. Backyard chicken samples $(n=60)$ revealed an intermediate level of AIV positivity, with 12, 17, 4 and 5 samples testing positive using AIV Ag test, HA, ELISA, and H5N1-based RT-PCR, respectively. Again chicken samples collected from Netrokona district showed the highest number of positive samples.

As shown in Fig 3, there was no significant association $\left(\chi^{2}\right.$-test, $p$ value $\left.>0.05\right)$ between the percentage of positive samples detected by different methods and locations. As shown in Fig. 3B, for duck samples $(\mathrm{n}=180)$, it was found that $6.67 \%(\mathrm{n}=12), 8.33(\mathrm{n}=15), 55.55 \%(100)$, and $1.67 \%(\mathrm{n}=3)$ samples were positive using rapid AIV Ag test, HA, ELISA, and H5N1-based RT-PCR $\left(\chi^{2}\right.$-test, $p$ value $<0.0001$, significant association between the prevalence rate of AIV detected by different methods and species (ducks and chicken) and location of sampling). 
Although standard operating methods for sampling were established, it is also possible that methodological variations between different teams operating in different areas could account for regional differences. Finally, spatial data were also confounded by a temporal element as samples were taken at different times of year. Analysis of monthly data showed that the seasonal pattern and influenza activity were highest in winter season from November to February during 2013 and 2104 as shown in Fig. 4. This pattern is similar to results of previous studies which reported the high occurrence of H5N1 AIVs in winter months in Southeast Asia [50, 51]. This may be explained by the existence of migratory waterfowl birds in Bangladesh during this time period which play an active role in virus transmission and shedding into other domestic avian hosts. The dynamics and transmission of AIVs in asymptomatic infected wild migratory birds is complex and is not yet fully understood. In winter time, open water ponds in Bangladesh are shared by large numbers of migratory waterfowls and domestic semi-scavenging ducks. As a result, domestic ducks may get infected with AIVs from migratory waterfowls and subsequently act as a natural reservoir of AIVs and play a potential role in virus shedding without showing clinical disease. In the present study during May to June period, few AIVs were detected using molecular methods of RT-PCR which suggested that rainfall and humidity among other climatic factors are associated with the reported H5N1 outbreaks in Bangladesh.

The present results accounted for a relatively higher percentage of H5N1 AIVs than previously reported from Bangladesh [20], suggesting a potentially increasing prevalence and progression of circulating H5N1 AIVs in commercial, backyard chicken and duck flocks. This seems credible given that other studies have reported the existence of poor vaccination and biosecurity practices in backyard farms and the rearing domestic ducks in wetlands. Together these practices allow the 
mixing of different AIV subtypes between native domestic poultry, ducks, and wild migratory birds [16, 52, 53].

In the present study, the H7N9 AIV subtype could not be detected using conventional RT-PCR. Low pathogenicity $\mathrm{H} 7$ subtypes among other influenza subtypes including H1, H3, H9, and H10 have however, been detected from LBMs in other studies [20, 54]. Mixed infections of different AIVs subtypes have also been reported from migratory waterfowl avian samples $[34,35]$. The differences between the present study and other reports in the numbers and subtypes detected could be partially explained by the continuous dynamics of the circulation of AI in poultry which necessitate the continuous ongoing monitoring as well as the difference in the detection method applied. This highlights the importance of continuous surveillance programs in poultry and migratory waterfowls to monitor circulating strains: an early warning of emergent strains could facilitate the implementation of control measures that could prevent the introduction of AI infections into human populations.

Differences in the detection of AIV by RT-PCR and VI are probably explained in part by what the assay is detecting. VI can detect only viable virus, and virus that has been inactivated during shipping or by disinfectants will not be detected, whereas those latter viruses can be potentially detected by RT-PCR. In addition, all influenza viruses may not readily adapt to growth to detectable titers in embryonating chicken eggs. The differences in viral cellular tropism between IAVs accounts for the unavailability of a single cell type for virus isolation [33]. This explains why few samples $(n=10)$ in the present study were found to be matrix gene RT-PCR positive while VI-negative, which was similar to previous findings [55]. Although virus isolation in specific pathogen free (SPF), commercial eggs, or specific antibody negative (SAN) 
embryonating chicken eggs is a sensitive method, it may take up to 2 weeks to obtain results, require highly trained personnel, and a supply of ECEs [33, 35].

In the present study, 221 serum samples out of 326 serum samples that were collected in April 2014 from three districts of the greater Mymensingh area (Netrokona, Sherpur and Kishorgonj) were sampled from vaccinated layer chicken aged 22-40 weeks and sera were collected 1 month after vaccination. The results of ELISA assay for anti-H5 Abs of these 221 samples revealed that only 18 serum samples (8.1\%) were found to be positive for anti-H5 Abs as compared to unvaccinated birds $(n=105)$, where only 8 samples $(7.61 \%)$ were seropositive. Although this result could potentially indicate a vaccine strain mismatch, or that the currently applied vaccine for these birds should be revised and updated, it could be indicative of a spatiotemporally clustered sampling strategy in combination with a small sample size. This may have an adverse impact because long term circulation and persistence of AI viruses in vaccinated population may result in both antigenic and genetic viral changes [56]. The seropositivity of unvaccinated birds $(7.6 \%)$ reflects the occurrence of natural infection which may be due to the contact of these birds with migratory waterfowl or other potential sources of LPAIVs. Household ducks are reared on the same premises and are often in close contact with other hosts including poultry, livestock, and humans in the same property. Wild and domestic ducks are potential carriers of AIV subtypes and play a major role in the introduction of AIVs into other hosts including humans, poultry, and mammalian hosts [57]. Bangladesh is located in the region of East Asia where a major migration and breeding area for waterfowl in the Central Asian Flyway, an area extending from India, Bangladesh and Myanmar in the south to Siberia in the north. These native birds are important source for the transmission of AIVs among other farm birds. Both small scale commercial poultry farms with compromised and minimal biosecurity measures 
and household village chicken are widespread throughout Bangladesh [48]. Layer chickens transmit AIVs to humans via eggs and broilers through meat consumption. Domestic duck populations in Bangladesh are semi-scavenging and free-grazing and they become infected from synchronized wild migratory birds. Thus, domestic ducks play the most significant role in risk amplification of AIVs circulation and facilitate the transmission of AIVs between wild and domestic naive bird populations. This could be drawn from the results of the present study (Table 6), where the prevalence of anti-H5 antibodies among duck serum samples accounted for 55.5\% as compared to $8.9 \%$ in chicken samples out of the 360 samples collected between November 2013 and October, 2014 from four different locations (Rajshahi, Netrokona, Sherpur and Kishoregonj). The seroprevalence and molecular detection rates in duck samples were 55.6\% and $1.7 \%$ as compared detection rates in chicken samples 8.9 and 6.1. In the present study, we have detected H5 antibody only in duck sera using a commercial available competitive ELISA (H5 AIV Ab ELISA AniGen ELISA ${ }^{\circledR}$,BioNote, Suwon, Korea). We isolated live H5N1 virus from those antibody positive birds (duck). In case of chicken sera, we detected avian influenza antibodies using a different ELISA kit (BioChek, UK). In the present study, all H5 specific RTPCR positive duck samples were positive to H5 Ab ELISA. We have isolated H5N1 virus from dead bird (chicken) and collection of serum sample was not possible and only swab samples were collected and tested.

The findings of the present study showed that $34 \%$ ( $\mathrm{n}=545$ out of 1,603 ) duck samples were positive for $\mathrm{H} 5$ antibody and more than $50 \%$ (55.6\%) of 180 duck samples were tested positive for $\mathrm{H} 5 \mathrm{~N} 1$ antibodies as shown in Tables 5 and 6, hence this explain that duck populations act mainly as dynamic reservoir and carrier of H5N1 AIVs, and also plays a major role in the transmission of $\mathrm{H} 5 \mathrm{~N} 1$ viruses into other species including poultry. Further studies to 
determine the co infection of these samples with other viruses including but not limited to NDV using next generation sequencing are being conducted on these AIV positive samples to explore further details of epidemiological importance.

\section{Conclusions}

There are few recent data about AIV surveillance in Bangladesh. We have investigated the prevalence of AIVs including highly pathogenic H5N1 in poultry and duck in Bangladesh. Molecular detection methods and serological surveillance in Bangladesh shows evidence of presence of H5N1 influenza viruses among live domestic poultry and ducks and that ducks play a major role in the transmission of AIV to domestic poultry. The high prevalence of H5N1 influenza viruses in backyard poultry and LBM suggests that there is an urgent need to enhance surveillance program to insure the proper implementation of pandemic preparedness plans in the future. In addition, the finding that there is no difference in anti H5 seropositivity between vaccinated $(8.1 \%)$ and unvaccinated chickens $(7.61 \%)$ indicates a failure of the vaccination program and calls for the use of updated poultry vaccines. Several factors such as the vaccination scheme applied in Bangladesh poultry, the number of vaccination interventions, vaccines used and licensed (vaccine content and type), and age of birds at vaccinations are required to be addressed. Public health education, the application of strict biosecurity protocols, and proper hygienic practices by all personnel dealing with poultry are important preventive steps and well help mitigate the possible endemicity, reduce the spread and occurrence of seasonal epidemics due to AIVs in Bangladesh as well as in other areas where infection is endemic. Further studies are required to provide a clearer picture on the possible sources of these viruses including a national surveillance among wildlife and migratory birds. We are currently screening the samples collected in the present study for other possible existing AIVs subtypes as well as 
Newcastle disease virus (NDV) to better understand the epidemiology and dynamics of viral transmission and to help provide valuable preventive and control measures to control the spread of AIV subtypes as well as NDV among human and animal populations.

\section{Acknowledgements:}

This work has been funded in part with funds from the Food and Agriculture Organization (FAO) of the United Nations to support the FAO funded project "HPAI surveillance in human-duck-wild birds interface" and also funds from the World Bank thorough a subproject entitled "Development of Livestock and Poultry Vaccines (CP007)” under Higher Education Quality Enhancement Project, University Grants Commission of Bangladesh, Ministry of Education, Bangladesh. Its contents are solely the responsibility of the authors and do not necessarily represent the official views of the funder. The authors would like to thank farm owners for granting permission to sample birds. sampling. Special thanks to Dr David Suarez and Dr Patti J Miller from the Southeast Poultry Research Laboratory, United States National Poultry Research Center, Athens, GA 30605, USA for their personal communications with Dr Mohamed El Zowalaty and their valuable scientific revisions and critical reading of manuscript and valuable comments about the study. Any use of commercial diagnostic products, or firm names is for descriptive purposes only and does not imply endorsement.

\section{Authors' contributions}

Conceived and designed the experiments: MEZ, MBR, MTR, Performed the experiments: WKA, MSP, MFR, KNN, MSA, MH, MAK, MMA, MY, MR, NCD, GA, statistical analyses; MEZ, SJ, AIK, interpretation and analysis of the data; MEZ, MTR, MBR, draft and wrote the manuscript: MEZ, critical revision of the manuscript for intellectual content; MEZ, SB, SJ, HZ, AIK, MBT, 
MT, ANE, HA, MM. All authors read and approve the final manuscript. No other person has any role in the study design, data collection and analysis, preparation of the manuscript, or decision to publish.

Competing interests: The authors have declared that no competing interests exist 


\section{References}

1. Dudley JP: Public health and epidemiological considerations for avian influenza risk mapping and risk assessment. Ecology and Society 2008, 13(2):21.

2. Ip HS, Torchetti MK, Crespo R, Kohrs P, DeBruyn P, Mansfield KG, Baszler T, Badcoe L, Bodenstein B, Shearn-Bochsler V: Novel Eurasian Highly Pathogenic Avian Influenza A H5 Viruses in Wild Birds, Washington, USA, 2014. Emerging infectious diseases 2015, 21(5):886.

3. Ducatez MF, Olinger CM, Owoade AA, De Landtsheer S, Ammerlaan W, Niesters HG, Osterhaus AD, Fouchier RA, Muller CP: Avian flu: multiple introductions of H5N1 in Nigeria. Nature 2006, 442(7098):37.

4. Swayne DE, Halvorson DA, Y. M. Saif HJBAMFJRGLRM, Swayne DE: Influenza. In: Disease of poultry. edn. Iowa State University Press, Ames, IA; 2003: 135-160.

5. Cumulative number of confirmed human cases for avian influenza A (H5N1) reported to WHO, 2003-2016. [http://www.who.int/influenza/human_animal_interface/EN_GIP_20150623cumulativeN umberH5N1cases.pdf?ua=1]

6. Directorate General of Health Services Bangladesh. 2nd National Avian and Pandemic Influenza Preparedness and Response Plan, Bangladesh, 2009-2011 [ http://oldweb.dghs.gov.bd/bn/important-documents-software/category/7-2012-07-09-0743-26?download=6:2nd-national-avian-and-pandemic-influenza-preparedness-andresponse-plan-bangladesh]

7. Bangladesh Bureau of Statistics. 2011 Population and housing census: preliminary results 2011. [ 
http://www.bbs.gov.bd/WebTestApplication/userfiles/Image/BBS/PHC2011Preliminary \%20Result.pdf]

8. The World Bank. Implementation completion and results report (IDA-43400 TF90662) on a credit in the amount of SDR 10.5 million (US\$16.0 million equivalent) to the People's Republic of Bangladesh for an avian influenza preparedness and response project under the global program for avian influenza and human pandemic preparedness and response. Washington, DC: The World Bank, 2013 [ http://wwwwds.worldbank.org/external/default/WDSContentServer/WDSP/IB/2013/07/04/00044246 4_20130704100805/Rendered/PDF/ICR21770ICR0Av0Box0377341B00PUBLIC0.pdf]

9. World Health Organization. Cumulative number of confirmed human cases of avian influenza $\mathrm{A}(\mathrm{H} 5 \mathrm{~N} 1)$ reported to WHO [http://www.who.int/influenza/human_animal_interface/EN_GIP_20150501CumulativeN umberH5N1cases.pdf?ua=1]

10. Food and Agriculture Organization of the United Nations, World Organisation for Animal Health, World Health Organization. FAO-OIE-WHO technical update: current evolution of avian influenza H5N1 viruses [http://www.who.int/influenza/human_animal_interface/tripartite_notes_H5N1.pdf]

11. Rushton J, Viscarra R, Guerne-Bleich E, Mcleod A: Impact of Influenza Outbreaks in the Poultry Sectors of Five South-east Asian Countries (Cambodia, Indonesia, Lao PDR, Thailand, Viet Nam) Outbreak Costs, Responses and Potential Long-term Control. Food and Agriculture Organization of the United Nations. Retrieved 18 
July 2009. Availabe online at http://www.fao.org/docs/eims/upload/214194/rushtoncomp.pdf. Accessed 28 June 2015. In.; 2004.

12. Chan PK: Outbreak of avian influenza A (H5N1) virus infection in Hong Kong in 1997. Clinical Infectious Diseases 2002, 34(Supplement 2):S58-S64.

13. Omar M, Sabur S, Moniruzzaman M, Hoq M: Marketing channel, margin, and price behavior of egg in selected areas of Gazipur district. Journal of the Bangladesh Agricultural University 2014, 11(2):277-284.

14. Ahmed SSU, Themudo GE, Christensen JP, Biswas PK, Giasuddin M, Samad MA, Toft N, Ersbøll AK: Molecular epidemiology of circulating highly pathogenic avian influenza (H5N1) virus in chickens, in Bangladesh, 2007-2010. Vaccine 2012, 30(51):7381-7390.

15. Biswas P, Giasuddin M, Nath B, Islam M, Debnath N, Yamage M: Biosecurity and Circulation of Influenza A (H5N1) Virus in Live-Bird Markets in Bangladesh, 2012. Transboundary and emerging diseases 2015.

16. Biswas PK, Christensen JP, Ahmed SS, Barua H, Das A, Rahman MH, Giasuddin M, Hannan AS, Habib MA, Ahad A: Avian influenza outbreaks in chickens, Bangladesh. Emerging infectious diseases 2008, 14(12):1909.

17. Gerloff NA, Khan SU, Zanders N, Balish A, Haider N, Islam A, Chowdhury S, Rahman MZ, Haque A, Hosseini P: Genetically Diverse Low Pathogenicity Avian Influenza A Virus Subtypes Co-Circulate among Poultry in Bangladesh. PloS one 2016, 11(3):e0152131.

18. Haider N, Sturm-Ramirez K, Khan S, Rahman M, Sarkar S, Poh M, Shivaprasad H, Kalam M, Paul S, Karmakar P: Unusually high mortality in waterfowl caused by 
highly pathogenic avian influenza A (H5N1) in Bangladesh. Transboundary and emerging diseases 2015.

19. Paul M, Wongnarkpet S, Gasqui P, Poolkhet C, Thongratsakul S, Ducrot C, Roger F: Risk factors for highly pathogenic avian influenza (HPAI) H5N1 infection in backyard chicken farms, Thailand. Acta tropica 2011, 118(3):209-216.

20. Negovetich NJ, Feeroz MM, Jones-Engel L, Walker D, Alam S, Hasan K, Seiler P, Ferguson A, Friedman K, Barman S: Live bird markets of Bangladesh: H9N2 viruses and the near absence of highly pathogenic H5N1 influenza. PLoS One 2011, 6(4):e19311-e19311.

21. Ma C, Lam TT-Y, Chai Y, Wang J, Fan X, Hong W, Zhang Y, Li L, Liu Y, Smith DK: Emergence and evolution of H10 subtype influenza viruses in poultry in China. Journal of virology 2015, 89(7):3534-3541.

22. Webster RG: Evolution and ecology of influenza A viruses. Microbiology and molecular biology reviews 1992, 56(1):152.

23. Stallknecht DE: Ecology and Epidemiology of Avian Influenza Viruses in Wild Bird Populations: Waterfowl, Shorebirds, Pelicans, Cormorants, Etc. Avian Diseases 2003:61.

24. Slemons RD, Easterday BC: Virus replication in the digestive tract of ducks exposed by aerosol to type-A influenza. Avian Diseases 1978, 22(3):367-377.

25. Garten RJ, Davis CT, Russell CA, Shu B, Lindstrom S, Balish A, Sessions WM, Xu X, Skepner E, Deyde V et al: Antigenic and genetic characteristics of swine-origin 2009 A(H1N1) influenza viruses circulating in humans. Science (New York, NY) 2009, 325(5937):197-201. 
26. Munster VJ, Veen J, Olsen B, Vogel R, Osterhaus AD, Fouchier RA: Towards improved influenza A virus surveillance in migrating birds. Vaccine 2006, 24(4446):6729-6733.

27. Kim JK, Negovetich NJ, Forrest HL, Webster RG: Ducks: the "Trojan horses" of H5N1 influenza. Influenza and other respiratory viruses 2009, 3(4):121-128.

28. Tong S, Li Y, Rivailler P, Conrardy C, Castillo DAA, Chen L-M, Recuenco S, Ellison JA, Davis CT, York IA: A distinct lineage of influenza A virus from bats. Proceedings of the National Academy of Sciences 2012, 109(11):4269-4274.

29. Tong S, Zhu X, Li Y, Shi M, Zhang J, Bourgeois M, Yang H, Chen X, Recuenco S, Gomez J: New world bats harbor diverse influenza A viruses. PLoS Pathog 2013, 9(10):e1003657.

30. El Zowalaty ME, Bustin SA, Husseiny MI, Ashour HM: Avian influenza: virology, diagnosis and surveillance. Future microbiology 2013, 8(9):1209-1227.

31. Shan S, Ko LS, Collins RA, Wu Z, Chen J, Chan KY, Xing J, Lau LT, Yu AC: Comparison of nucleic acid-based detection of avian influenza H5N1 with virus isolation. Biochemical and biophysical research communications 2003, 302(2):377-383.

32. Agüero M, San Miguel E, Sanchez A, Gomez-Tejedor C, Jimenez-Clavero MA: A fully automated procedure for the high-throughput detection of avian influenza virus by real-time reverse transcription-polymerase chain reaction. Avian Diseases 2007, 51(1 Suppl):235-241.

33. Fouchier RAM, Bestebroer TM, Herfst S, Van Der Kemp L, Rimmelzwaan GF, Osterhaus ADME: Detection of influenza A viruses from different species by PCR 
amplification of conserved sequences in the matrix gene. Journal of clinical microbiology 2000, 38(11):4096-4101.

34. El Zowalaty ME, Abin M, Chander Y, Redig PT, Goyal SM: Isolation of H5 Avian Influenza Viruses from Waterfowl in the Upper Midwest Region of the United States. Avian Diseases 2011, 55(2):259-262.

35. El Zowalaty ME, Abin M, Raju S, Chander Y, Redig PT, El Latif HKA, El Sayed MA, Goyal SM: Isolation of avian influenza virus from polymerase chain reactionnegative cloacal samples of waterfowl. Journal of Veterinary Diagnostic Investigation 2011, 23(1):87-90.

36. Krauss S, Walker D, Webster RG: Influenza virus isolation. Methods in molecular biology (Clifton, NJ) 2012, 865:11-24.

37. Ollier L, Caramella A, Giordanengo V, Lefebvre JC: High permissivity of human HepG2 hepatoma cells for influenza viruses. Journal of clinical microbiology 2004, 42(12):5861-5865.

38. Salgado C, Farr B, Hall K, Hayden F: Influenza in the acute hospital setting. The Lancet infectious diseases 2002, 2(3):145.

39. Simpson J, Moric I, Wark PAB, Johnston S, Gibson P: Use of induced sputum for the diagnosis of influenza and infections in asthma: a comparison of diagnostic techniques. Journal of clinical virology 2003, 26(3):339.

40. Spackman E: Viral diagnostics: will new technology save the day. Avian Pathology 2012, 41(3):251-258.

41. Cardona C, Slemons R, Perez D: The prevention and control of avian influenza: The avian influenza coordinated agriculture project. Poultry science 2009, 88(4):837-841. 
42. BelA $\tilde{}_{i} \mathrm{k}$ S: New developments in the diagnosis of avian influenza. Revue scientifique et technique 2009, 28(1):233.

43. Dusek RJ, Bortner JB, DeLiberto TJ, Hoskins J, Franson JC, Bales BD, Yparraguirre D, Swafford SR, Ip HS: Surveillance for high pathogenicity avian influenza virus in wild birds in the Pacific Flyway of the United States, 2006-2007. Avian Diseases 2009, 53(2):222-230.

44. World Health Organization. Recommendations and laboratory procedures for detection of avian influenza A (H5N1) virus in specimens from suspected human cases. World Health Organization 2007.

45. Hirst GK: The agglutination of red cells by allantoic fluid of chick embryos infected with influenza virus. Science 1941, 94(2427):22-23.

46. Hoffmann E, Stech J, Guan Y, Webster RG, Perez DR: Universal primer set for the full length amplification of all influenza A viruses. Archives of Virology 2001, 146(12):2275-2289.

47. Kang H-M, Lee E-K, Song B-M, Jeong J, Choi J-G, Jeong J, Moon O-K, Yoon H, Cho Y, Kang Y-M: Novel reassortant influenza A (H5N8) viruses among inoculated domestic and wild ducks, South Korea, 2014. Emerging infectious diseases 2015, 21(2):298.

48. Khatun A, Giasuddin M, Islam KM, Khanom S, Samad MA, Islam MR, Noor M, Bhuiyan JU, Kim W-I, Eo SK: Surveillance of avian influenza virus type A in semiscavenging ducks in Bangladesh. BMC veterinary research 2013, 9(1):196. 
49. Nooruddin G, Hossain M, Mohammad M, Rahman M: Sero-epidemiology of avian influenza virus in native chicken in Bangladesh. International Journal of Poultry Science 2006, 5(11):1029-1033.

50. Park AW, Glass K: Dynamic patterns of avian and human influenza in east and southeast Asia. The Lancet infectious diseases 2007, 7(8):543-548.

51. Saha S, Chadha M, Al Mamun A, Rahman M, Sturm-Ramirez K, Chittaganpitch M, Pattamadilok S, Olsen SJ, Sampurno OD, Setiawaty V: Influenza seasonality and vaccination timing in tropical and subtropical areas of southern and south-eastern Asia. Bulletin of the World Health Organization 2014, 92(5):318-330.

52. Barua A, Yoshimura Y: Rural poultry keeping in Bangladesh. World's Poultry Science Journal 1997, 53(04):387-394.

53. Newman SH, Hill NJ, Spragens KA, Janies D, Voronkin IO, Prosser DJ, Yan B, Lei F, Batbayar N, Natsagdorj T: Eco-virological approach for assessing the role of wild birds in the spread of avian influenza H5N1 along the Central Asian Flyway. 2012.

54. Shi J, Deng G, Liu P, Zhou J, Guan L, Li W, Li X, Guo J, Wang G, Fan J: Isolation and characterization of $\mathrm{H7N9}$ viruses from live poultry markets-implication of the source of current H7N9 infection in humans. Chin Sci Bull 2013, 58(16):1857-1863.

55. Spackman E, Senne DA, Myers T, Bulaga LL, Garber LP, Perdue ML, Lohman K, Daum LT, Suarez DL: Development of a real-time reverse transcriptase PCR assay for type A influenza virus and the avian $\mathbf{H 5}$ and $\mathbf{H 7}$ hemagglutinin subtypes. Journal of clinical microbiology 2002, 40(9):3256-3260.

56. Grund C, Abdelwhab E-SM, Arafa A-S, Ziller M, Hassan MK, Aly MM, Hafez HM, Harder TC, Beer M: Highly pathogenic avian influenza virus H5N1 from Egypt 
escapes vaccine-induced immunity but confers clinical protection against a heterologous clade 2.2. 1 Egyptian isolate. Vaccine 2011, 29(33):5567-5573.

57. Chen H, Smith GJ, Zhang SY, Qin K, Wang J, Li KS, Webster RG, Peiris JS, Guan Y: Avian flu: H5N1 virus outbreak in migratory waterfowl. Nature 2005, 436(7048):191-192. 
Fig. 1. Administrative divisions of Bangladesh showing sample locations. Reproduce from the world Factbook. Available at the CIA website https://www.cia.gov/ library/publications/theworld-factbook/index.html. (accessed 15 August 2015).

Fig. 2. Diagnostic test results of samples $(n=360)$ collected from four different locations between November 2013 and October, 2014. Geographical distribution of (A) RTK, (B) HA, (C) ELISA, and (D) H5 RT-PCR test results of swab samples of chickens and ducks.

Fig. 3. Virological test results for the detection of H5N1 AIV in chicken (CK) and duck samples (n=360) from four different locations between November 2013 and October 2014.

Fig.4. AIV test results of (A) duck $(n=180)$ and $(B)$ chicken $(n=180)$ samples collected from Bangladesh between November 2013 and October, 2014. 
Table 1. Field cloacal and oropharyngeal samples collected from different districts in Bangladesh.

\begin{tabular}{llllll}
\hline $\begin{array}{l}\text { Type of sample } \\
\text { collected }\end{array}$ & \multicolumn{5}{c}{ District } \\
\cline { 2 - 6 } & Surveillance & Kishorgonj & Netrokona & Rajshahi & Sherpur \\
& Project & $\mathbf{n}(\%)$ & $\mathbf{n}(\%)$ & $\mathbf{n}(\%)$ & $\mathbf{n}(\%)$ \\
\hline Cloacal (C) & A & $320(78)$ & $223(14.9)$ & 0 & $86(48.9)$ \\
& B & $90(22)$ & $90(6)$ & $90(100)$. & $90(51.1)$ \\
& C & 0 & $1180(79)$ & 0 & 0 \\
$\begin{array}{l}\text { Oropharyngeal } \\
\text { (OP) }\end{array}$ & A & 410 & 1493 & 90 & 176 \\
& B & $328(78.5)$ & $237(15.7)$ & 0 & $86(48.9)$ \\
& C & $90(21.5)$ & $90(6.0 \%)$ & $90(100)$ & $90(51.1)$ \\
& District total (n) & 0 & $1180(78.3)$ & 0 & 0 \\
\hline
\end{tabular}


Table 2. Number of pooled and individual $\mathrm{C}$ and $\mathrm{OP}$ samples collected from different districts in Bangladesh.

\section{Type of Samples}

District

Cloacal

Oropharyngeal

Pooled samples

\begin{tabular}{lcccccccc}
\cline { 2 - 8 } & collected & $\begin{array}{c}\text { Discarded } \\
(\mathbf{l o w} \\
\text { quality) }\end{array}$ & collected & $\begin{array}{c}\text { Discarded } \\
\text { (low } \\
\text { quality })^{\mathbf{a}}\end{array}$ & $\begin{array}{c}\mathbf{C}+ \\
\text { OP }\end{array}$ & $\begin{array}{c}\text { C } \\
\text { only }\end{array}$ & $\begin{array}{c}\text { OP } \\
\text { only }\end{array}$ & $\begin{array}{c}\text { Total tested } \\
(\mathbf{C + O P}+\mathbf{C + O P}\end{array}$ \\
\hline Kishorgonj & 410 & 8 & 418 & 13 & 402 & 0 & 3 & 405 \\
Netrokona & 1493 & 8 & 1507 & 7 & 1485 & 0 & 15 & 1500 \\
Sherpur & 176 & 19 & 176 & 20 & 156 & 1 & 0 & 157 \\
Rajshahi & 90 & 0 & 90 & 0 & 90 & 0 & 0 & 90 \\
Total & 2169 & 35 & 2191 & 40 & 2133 & 1 & 18 & 2152 \\
\hline
\end{tabular}

${ }^{a}$ Samples that did not contain enough sample volume were classified as low quality samples and were discarded. 
Table 3. Matrix and H5N1 specific RT-PCR results of C and OP samples collected from different districts in Bangladesh.

\begin{tabular}{clll}
\hline District & $\begin{array}{l}\text { Total pooled C }+ \\
\text { OP samples }\end{array}$ & $\begin{array}{l}\text { M gene positive } \\
\text { pooled samples } \\
\text { n }(\%)\end{array}$ & $\begin{array}{l}\text { Number of H5N1 } \\
\text { AIV positive } \\
\text { samples }\end{array}$ \\
& n & n \\
\hline Kishorgonj & 405 & $8(2.0)$ & 5 \\
Netrokona & 1500 & $25(1.7)$ & 23 \\
Sherpur & 157 & $3(1.9)$ & 1 \\
Rajshahi & 90 & $5(5.6)$ & 2 \\
All districts & 2152 & $41(1.9)$ & 31 \\
combined & & & \\
\hline
\end{tabular}


Table 4. AIV serum samples collected from domestic poultry in Bangladesh.

\begin{tabular}{llllll}
\hline $\begin{array}{l}\text { Type of } \\
\text { sample } \\
\text { collected }\end{array}$ & Surveillance & District & & \\
& project & Kishorgonj & Netrokona & Rajshahi & Sherpur \\
\cline { 3 - 6 } & & $\mathbf{n}(\boldsymbol{\%})$ & $\mathbf{n}(\%)$ & $\mathbf{n}(\%)$ & $\mathbf{n}(\boldsymbol{\%})$ \\
\hline Blood sera & A & $270(75.0)$ & $43(3.7)$ & 0 & $13(12.6)$ \\
& B & $90(25.0)$ & $90(7.7)$ & $90(100)$ & $90(87.4)$ \\
& C & 0 & $1039(88.7)$ & 0 & 0 \\
& $\begin{array}{l}\text { District total } \\
\text { (n) }\end{array}$ & 360 & 1172 & 90 & 103 \\
\hline
\end{tabular}


Table 5. Serological screening results of AIV serum samples in domestic poultry from Bangladesh.

\begin{tabular}{llllll}
\hline $\begin{array}{l}\text { Type of } \\
\text { serum } \\
\text { samples }\end{array}$ & $\begin{array}{l}\text { Kishorgonj } \\
\mathbf{n}(\%)\end{array}$ & $\begin{array}{l}\text { Netrokona } \\
\mathbf{n}(\%)\end{array}$ & $\begin{array}{l}\text { Rajshahi } \\
\mathbf{n}(\boldsymbol{\%})\end{array}$ & $\begin{array}{l}\text { Sherpur } \\
\mathbf{n}(\boldsymbol{\%})\end{array}$ & $\begin{array}{l}\text { District } \\
\text { total } \\
\mathbf{n}(\boldsymbol{\%})\end{array}$ \\
\hline Collected & 360 & 1172 & 90 & 103 & 1725 \\
Tested & 360 & $1050^{*}$ & 90 & 103 & 1603 \\
$\begin{array}{l}\mathrm{H} 5 \mathrm{Ab} \\
\text { positive }\end{array}$ & $62(17.2)$ & $447(42.6)$ & $13(14.4)$ & $23(22.3)$ & $545(34)$ \\
\hline
\end{tabular}

*It was not possible to test an additional 122 additional samples collected in Netrokona district due to a shortage in test kits supply. 
Table 6. Comparison of the different viral diagnostic test results for the detection of H5N1 AIV in chicken (CK) and duck samples between November 2013 and October 2014.

\begin{tabular}{|c|c|c|c|c|c|}
\hline \multirow{2}{*}{$\begin{array}{l}\text { Samples } \\
\text { location }\end{array}$} & \multirow[t]{2}{*}{ Type of birds ${ }^{\text {a }}$} & \multicolumn{4}{|c|}{ Number of samples positive } \\
\hline & & $\begin{array}{l}\text { Rapid AIV } \\
\text { antigen Test }\end{array}$ & $\mathbf{H A}^{\mathrm{b}}$ & $\begin{array}{l}\text { H5 Ab } \\
\text { ELISA }\end{array}$ & $\begin{array}{l}\text { H5N1 }{ }^{\mathrm{c}} \\
\text { RT-PCR }^{2}\end{array}$ \\
\hline \multirow[t]{4}{*}{ Rajshahi } & Duck & 1 & 3 & 10 & 0 \\
\hline & Broiler & 2 & 4 & 1 & 0 \\
\hline & Layer & 1 & 1 & 1 & 1 \\
\hline & Backyard CK & 3 & 4 & 1 & 1 \\
\hline \multirow[t]{4}{*}{ Netrokona } & Duck & 5 & 6 & 37 & 2 \\
\hline & Broiler & 1 & 2 & 0 & 0 \\
\hline & Layer & 9 & 11 & 4 & 4 \\
\hline & Backyard CK & 7 & 10 & 3 & 3 \\
\hline \multirow[t]{4}{*}{ Kishorganj } & Duck & 4 & 4 & 32 & 1 \\
\hline & Broiler & 1 & 1 & 1 & 1 \\
\hline & Layer & 4 & 5 & 2 & 0 \\
\hline & Backyard CK & 2 & 3 & 1 & 0 \\
\hline \multirow[t]{7}{*}{ Sherpur } & Duck & 2 & 2 & 21 & 0 \\
\hline & Broiler & 1 & 2 & 1 & 0 \\
\hline & Layer & 0 & 2 & 1 & 1 \\
\hline & Backyard CK & 0 & 0 & 0 & 0 \\
\hline & Duck & $12(6.7)$ & $15(8.3)$ & $100(55.6)$ & $3(1.7)$ \\
\hline & $\mathrm{CK}$ & $31(17.2)$ & $45(25)$ & $16(8.9)^{\mathrm{d}}$ & $11(6.1)$ \\
\hline & Total positive & 43 (11.9) & $60(16.7)$ & $116(32.2)$ & $14(3.9)$ \\
\hline
\end{tabular}

\footnotetext{
a Number of duck samples ( $\mathrm{n}=180)$ and number of chicken samples $(\mathrm{n}=180$; broiler, layer, and backyard, each is 60 samples)

${ }^{\mathrm{b}}$ Hemagglutination results after egg inoculation of samples were tested only for AIV. Other hemagglutinating agents were not shown in the present study, however these samples are being tested for other hemagglutinating agents.

${ }^{c}$ Number of H5N1 AIV samples that could be subtyped using specific H5 and N1 primers.
} 
d These samples were positive only for avian influenza antibodies using ELISA kit (BioChek, $\mathrm{UK})$. 


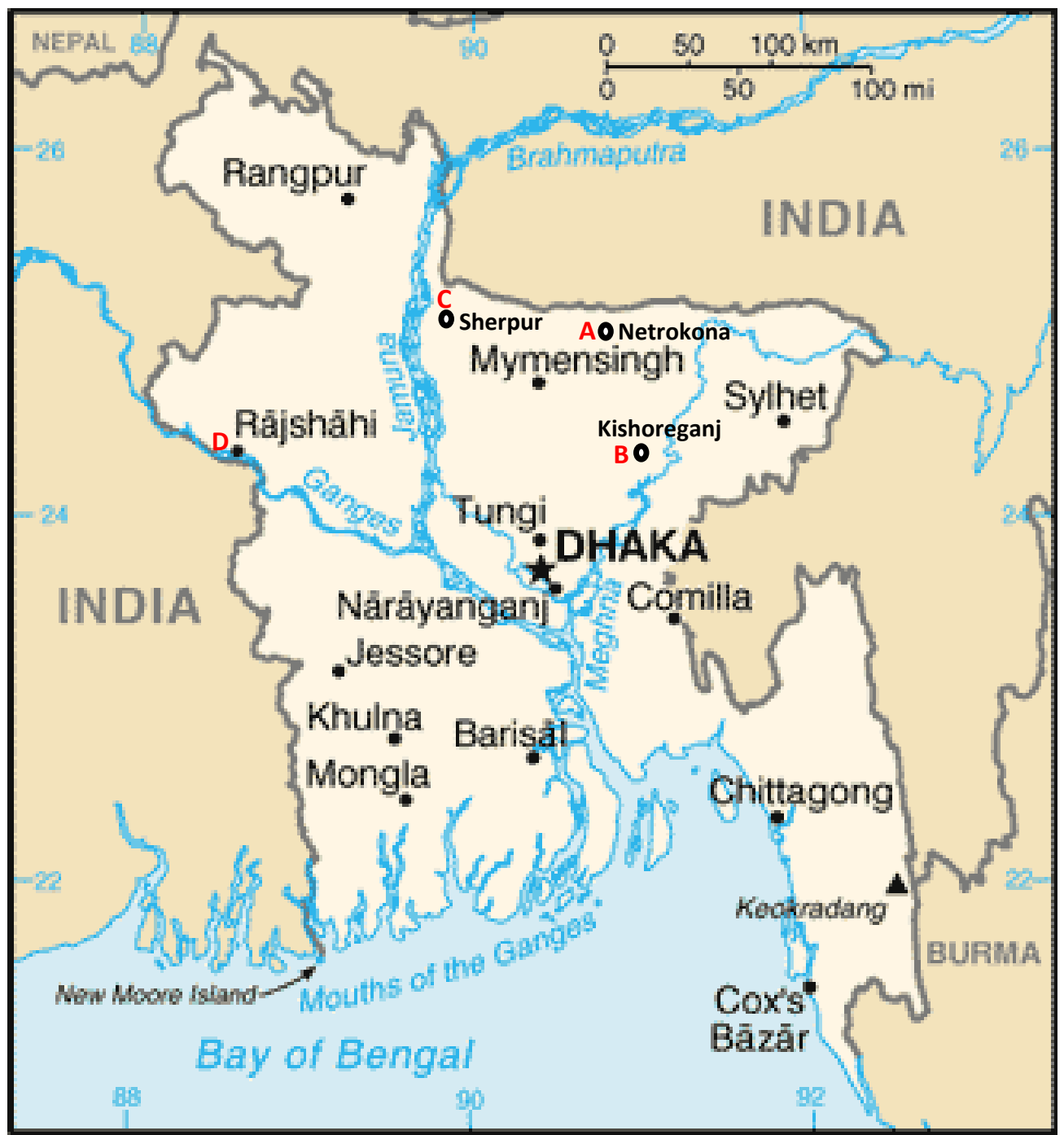

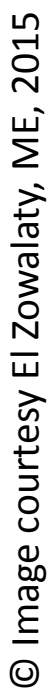


A

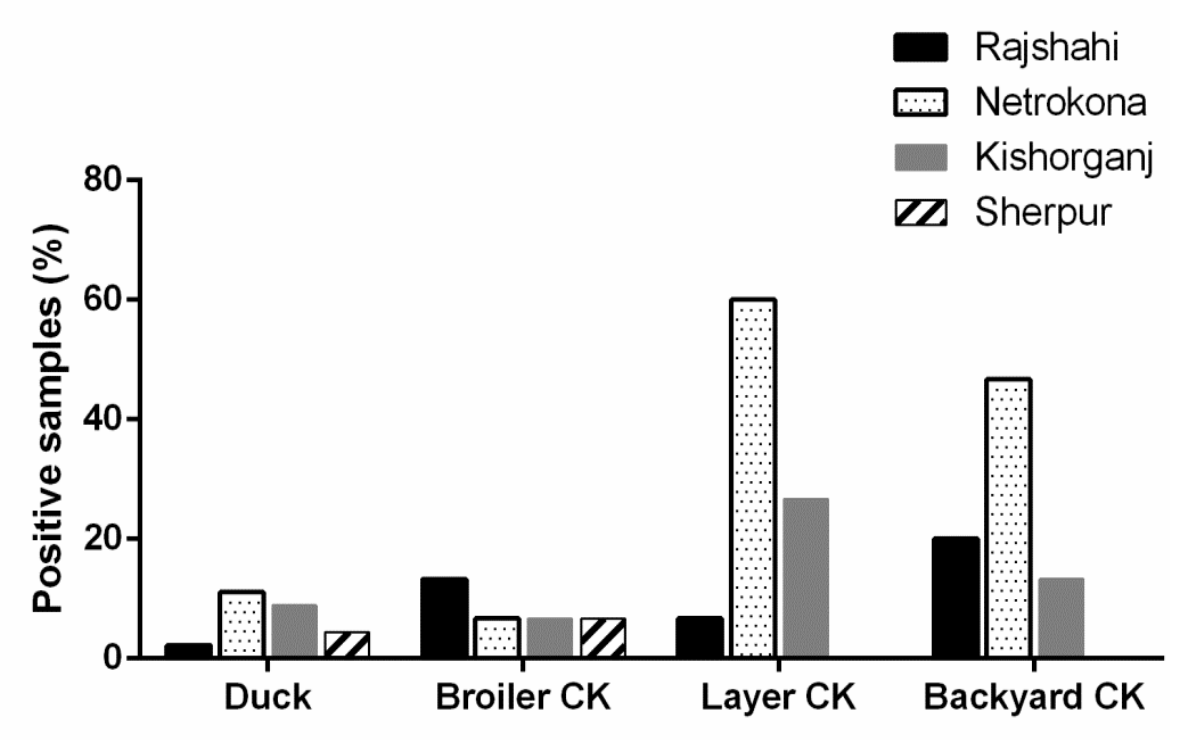

C
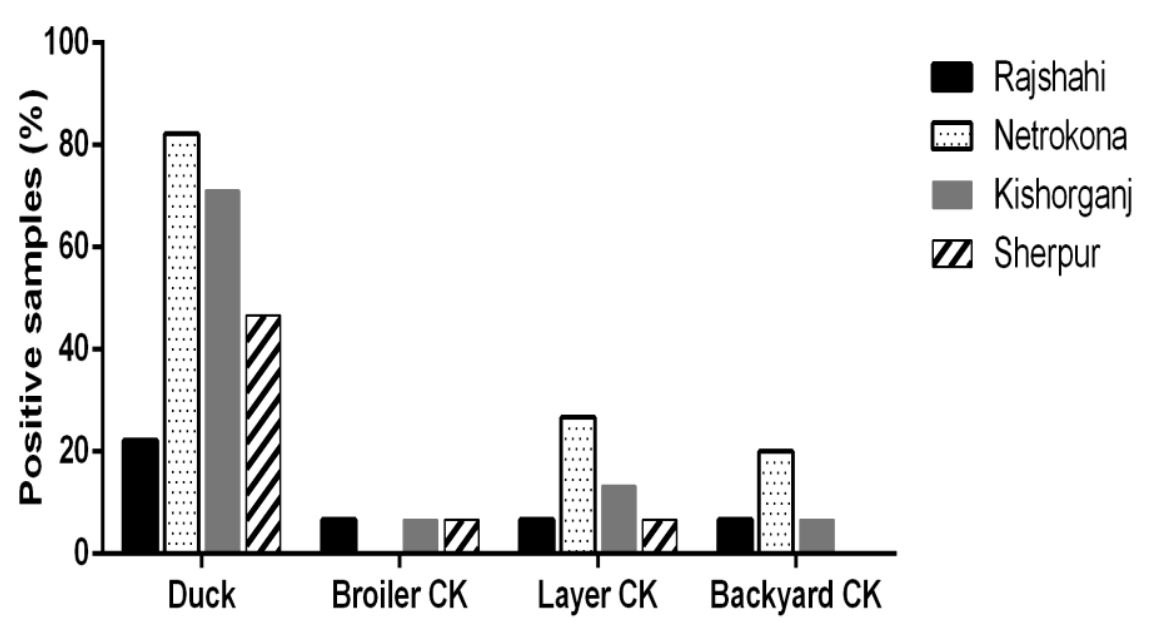
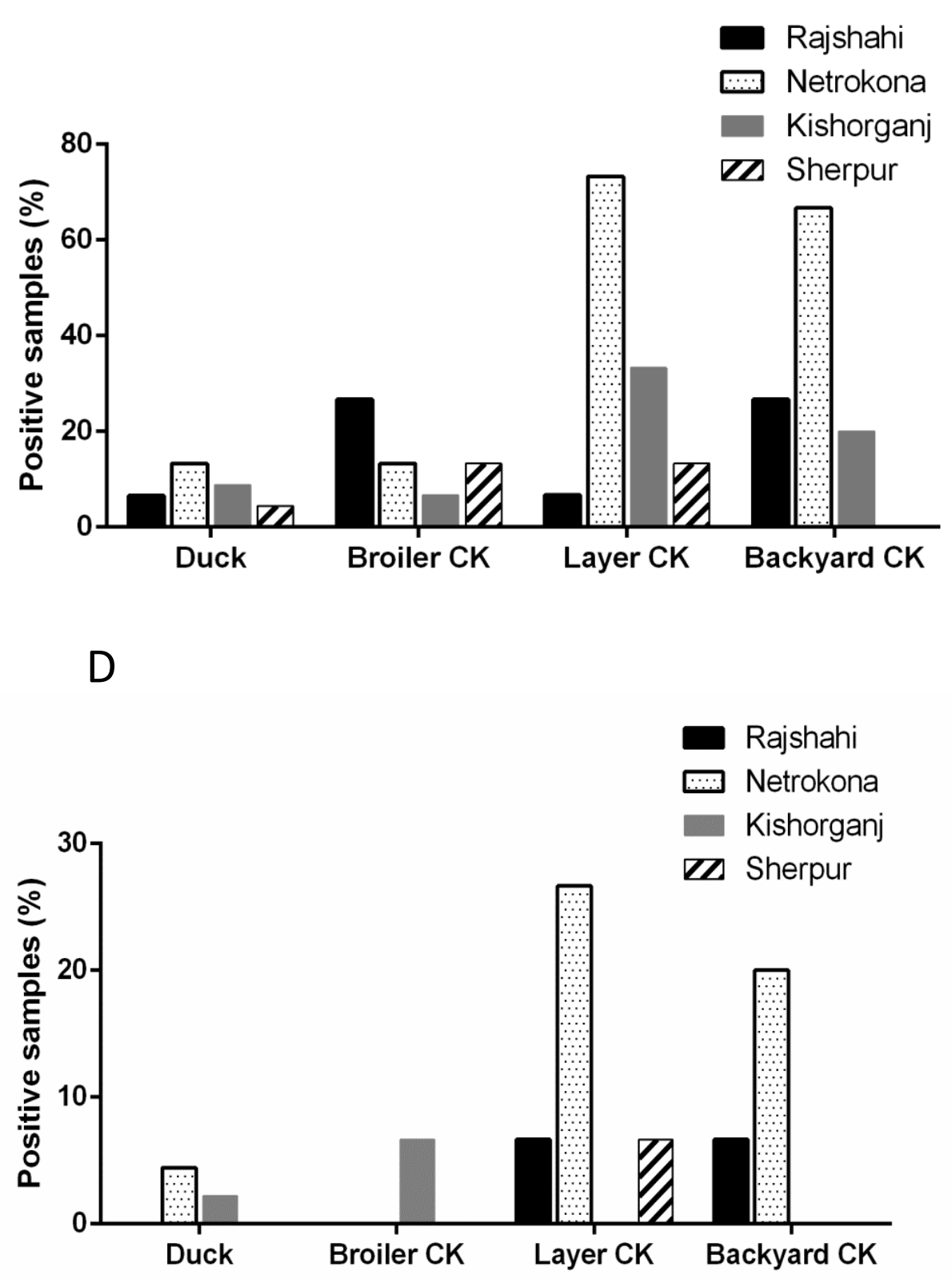

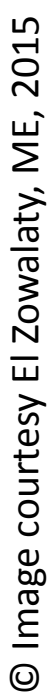




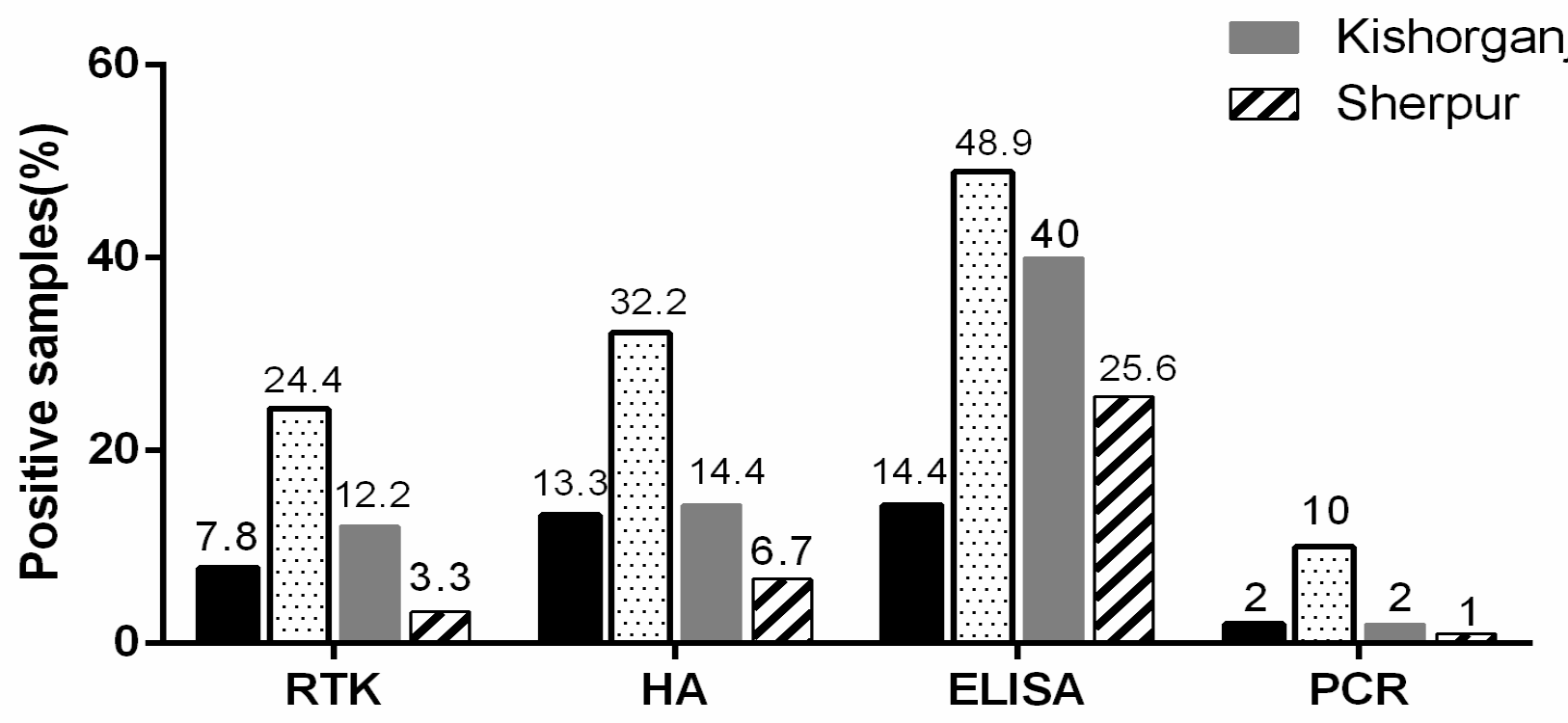

B

- Rapid AIV Ag

$\square$ HA

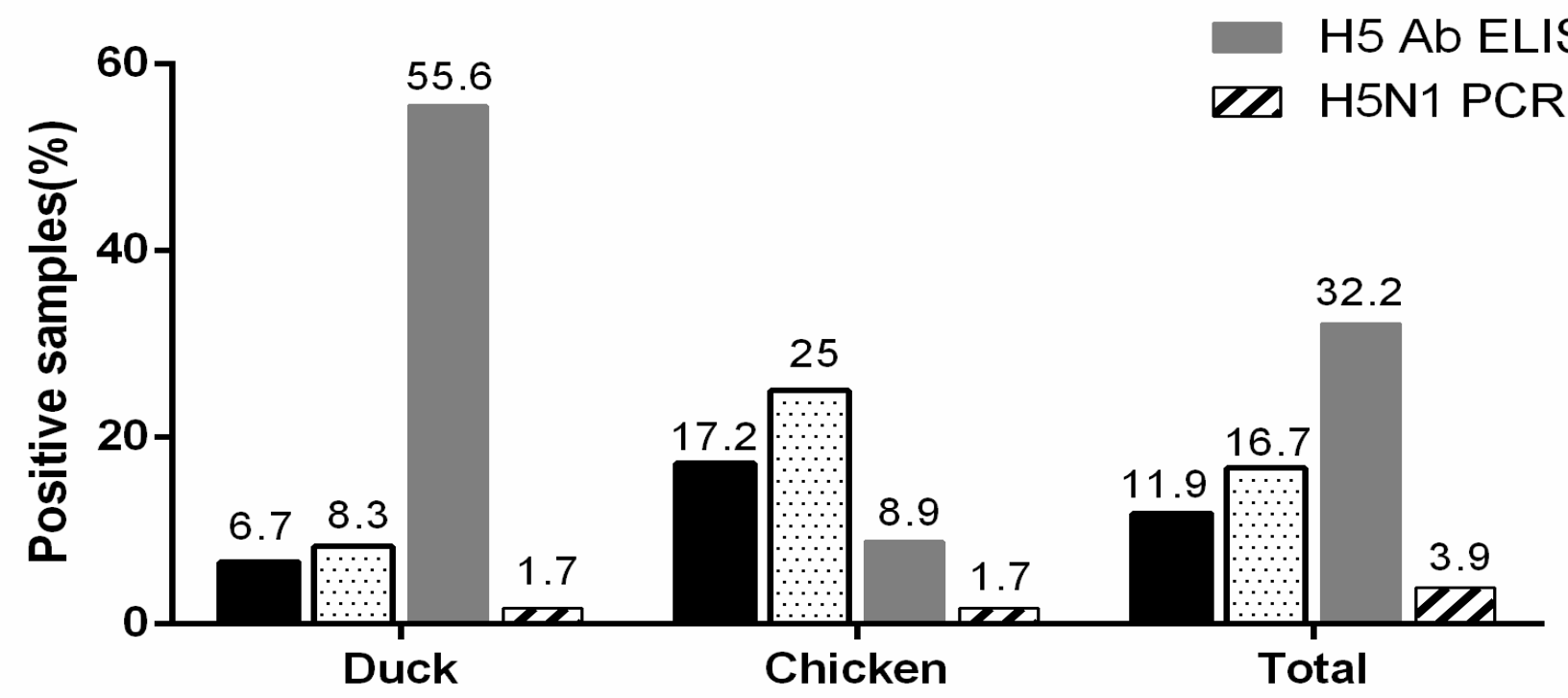

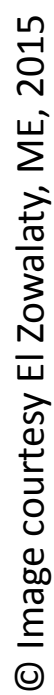


